\title{
EFFECT OF SOME INSECTICIDES ON CERTAIN ENZYMES OF SPODOPTERA LITTORALIS (BOSID.)
}

\author{
HANAN, S. ABD-EL-AZIZ
}

Plant Protection Res. Inst., ARC, Dokki, Giza, Egypt.

(Manuscript received 21 January 2014)

\begin{abstract}
The effects of three new insecticides belonging to different groups on some enzyme activities of the $4^{\text {th }}$ instar larvae of Spodoptera littoralis were studied. The results proved that the three tested insecticides i.e. Indoxacarb, Emamectin benzoate and Pyridalyl inhibited all the enzymes. In this investigation, Indoxacarb was the most inhibitive of a- esterase and GST activities. Emamectin benzoate, resulted in pronounced inhibition of GOT, LDH. But , Pyridalyl induced significant stimulation of GPT, LDH and $\beta$ - esterase.

Key words: S. littoralis, indoxacarb, pyridalyl, emamectin, a - esterase , $\beta$-esterase, Gpt, Got, glutathione-S-transferase (Gst) and LDH.
\end{abstract}

\section{INTRODUCTION}

Cotton plants in Egypt and other countries in Africa and Asia were attacked by the cotton leafworm $S$. littoralis caused great damage to many vegetables and fruits as zoell.

Due to the continuous use of chemical pesticides against this pest, resistance to the action of pesticides had been dramatically involved. So it is urgently needed to achieve new insecticides with new specific mode of action.

Three new commercial insecticides, namely Emamectin benzoate (1.9\% EC) (Methylamin, Avermactin) belongs to Avermactin group of chemicals produced by the soil-dwelling actinomycete, Streptomycen avermititis. It represented a second generation of Abamectin in Avermactin family which acts as nerve poisons stimulate the gama- aminobutyric acid (GABA) system, chemical- transmitter produced at nerve ending (Fritz et al., 1979) which block the post synaptic potential of neuro muscular junction leading to paralysis and finally to the death. It is more environmentally acceptable because it binds to the soil and doesn't degrade rapidly (Lasota and Dybas 1991). Higher detoxification associated with cuticular penetration, internal accumulation, excretion of applied toxicants and their metabolities occurred more rapidly in larvae than adults (Leona and Slynko, 1998).

Indoxacarb (Avaunt $15 \% \mathrm{SC}$ ) has a good toxin effect as a new class of oxidiazine insecticide against lepidoptera pest with nearly no effect on non target insects by blocking the movement of sodium ion and cause stop feeding and paralysis (Dinter 
and wiles, 2000). Pyridalyl is a new synthetic insecticide which has contact and ingestion toxic and good for lepidoptera pest control.

The target of the present work was directed to focus out the change in the activities of some important enzymes i.e. non specific esterase a and $\beta$-esterases, GOT, GPT, LDH and GST as a results of treatment with the $\mathrm{LC}_{50}$ values of emamectin benzoate, pyridalyl and indoxicarb for $48 \mathrm{hrs}$ as well as the recovery of these compounds in the whole body tissues of the $4^{\text {th }}$ instar larvae of $S$. littoralis.

\section{MATERIALS AND METHODS}

\section{Test insect:}

The laboratory strain of the cotton leafworm Spodoptera littoralis culture was obtained from the Department of cotton leafworm of Plant Protection research institute, Doki, Egypt. It was reared on castor bean leaves under laboratory condition at $25 \pm 2 \mathrm{C}$ and RH. $65 \pm 5 \%$ as methods described by El Defrawi et al., (1964).

\section{Chemical insecticides used:}

Emamectin benzoate (Radical 1.9\%Ec) produced by Agromen chemical co., LTd. Pyridalyl (pelo-5-1812,50\%EC) produced by sumitomo chemical. Co., LTd. Indoxacarb (Avant 15\% SE), produced by Dupont.

\section{Bioassays:}

Serial concentrations of emamactin benzoate, pyridalyl and indoxacarb were prepared. Fresh castor bean leaves were dipped in each concentration for (20) sec. Then treated leaves were left to dry at room temperature and then offered to $(20) 4^{\text {th }}$ instar larvae replicated 3-4 times to feed for 48 hrs-the estimated LC $_{50}$ values were 0.54 ,3.94 and $9.7 \mathrm{ppm}$ for emamectin benzoate, pyridalyl and indoxacarb, respectively The control larvae were fed on untreated leaves. The whole body tissues of larvae were collected for enzymes activity determination.

\section{Sample preparation}

10-15 treated larvae were homogenizing in distilled water $(1 \mathrm{gm} / \mathrm{ml})$ using hard glass homogenizer on ice jacket then centrifuged at 8000 r.p.m for $15 \mathrm{~min}$ at $5 \mathrm{c}$. The supernatant were kept at $-20 \mathrm{C}^{\circ}$ till used.

\section{Enzyme activity:}

a- $\quad a-$ and $\beta$ - non specific esterases were determined according to Van Asperen (1962) method using a- naphthyl acetate or $\beta$ - naphthyl acetate as substrates, respectively. 
b- Glutamic oxaloacetic transaminase (GOT) and glutamic pyruvic transaminase (GPT) were evaluated colormetrically according to the method of Reitman and Frankle (1957).

c- Glutathion- S- transferase (GSt) catalyzes the conjugation of reduce glutathione (GSH) with 1-chloro2, 4,-dinitrobenzen (CDNB) via the -SH group of glutathione. The conjugated S-(2,4-dintro-phenyl) -L- glutathione could detected as described by the method of Habig et al. (1974).

d- Lactic dehydrogenase (LDH) activity was determined based on the method described here is

derived from the formulation recommended by the German Society for clinical chemistry (Deutsche Gesellschaft FÜr Klinische Chemie 1972).

\section{Statistics Loudying:}

The data were analyzed using analysis of variance two way (ANOVA) using costat statistical software.

Activity Ratio= enzymatic activity of tested strain/ enzymatic activity of control

\section{RESULTS AND DISCUSSION}

\section{1- Non specific esterases:}

\section{a - a- esterases}

The data represented in Table (1) and illustrated in Fig (1) showed a high significant inhibitory effect in a - esterase. This inhibition (reduction) ranged between $(-6.71$ and $-48.16 \%)$ with indoxacab and emamectin, respectively while pyridalyl cause low significant inhibition to (-6.71\%) compared to control.

According to activity ratio represented in Table (1) and Fig (2), the obtained values $0.52,0.7$ and 0.93 times less for indoxacarb, emamectin benzoate and pyridalyl compared with the control.

Table 1 . changes in a - esterases activity of $S$. littoralis post 48 hrs of treatment $4^{\text {th }}$ instar larvae with $\mathrm{LC}_{50}$ values of three insecticides.

\begin{tabular}{|c|c|c|c|c|}
\hline Insecticides & Indoxacarb & Emamectin & Pyridalyl & control \\
\hline$*$ Mean \pm SE & $432.67 \pm 10.4 \mathrm{~d}$ & $584.0 \pm 11.79 \mathrm{c}$ & $778.67 \pm 8.69 \mathrm{~b}$ & $843.67 \pm 16.7 \mathrm{~b}$ \\
\hline Change\% & -48.16 & -30.03 & -6.71 & - \\
\hline Activity ratio & 0.52 & 0.70 & 0.93 & - \\
\hline F value & \multicolumn{4}{|c|}{$225.96 * * *$} \\
\hline L.S.D & 40.008 & \\
\hline
\end{tabular}

*Mean with the same letter are not significant different.

*Mean: Ug a naphthol/min/g.b.wt.

SE: Stander error. 


\section{b- $\boldsymbol{\beta}$ - esterases}

In Table (2) and Fig (1) showed a significant changes in the activity of $\beta$ esterase resulted from the treated $4^{\text {th }}$ instar larvae with $\mathrm{LC}_{50}$ values of the tested insecticides. Indoxacarb and emamectin benzoate caused significant reduction of 29.68 and $-27.30 \%$ compared with the control but, it was obvious that there were no significant differences between the efficacy of the two products on the enzyme activity. In the contrary, pyridalyl caused little increase in the enzymatic activity by $+8.35 \%$ than control.

Depending on the activity ratio as shown in Table (2) and detected in Fig (2) pyridalyl was 1.08 but the activity ratios of indoxacarb and emamectin benzoate were 0.7 and 0.73 .

Table 2. changes in $\beta$ - esterase activity of $S$. littoralis post $48 \mathrm{hrs}$ of treatment $4^{\text {th }}$ instar larvae with $\mathrm{LC}_{50}$ values of three insecticides.

\begin{tabular}{|c|c|c|c|c|}
\hline Insecticides & Indoxacarb & Emamectin & Pyridalyl & control \\
\hline$*$ Mean \pm SE & $530.67 \pm 9.21 \mathrm{c}$ & $548.67 \pm 12.35 \mathrm{c}$ & $817.67 \pm 5.3 \mathrm{a}$ & $754.67 \pm 21.7 \mathrm{~b}$ \\
\hline Change\% & -29.68 & -27.30 & +8.35 & - \\
\hline Activity ratio & 0.703 & 0.73 & 1.08 & - \\
\hline F value & \multicolumn{3}{|c}{$8.844^{* * *}$} & \\
\hline L.S.D & 50.102 & \\
\hline
\end{tabular}

*Mean with the same letter are not significant different.

*Mean: Ug $\beta$ naphthol/min/g.b.wt.

SE: Stander error.

The three tested insecticides caused a high significant reduction in both $a$ and $\beta$ esterase except pyridalyl which caused a significant increase in $\beta$-esterase. These results were in harmony with those recorded by Fahmy and Dahi (2009). The same reduction were obtained by Bakr et al., (2010). It be concluded that non- specific esterase play an important role in the metabolites of the insecticides.

Our results are accordance with those published by Anwar and Abdel-Mageed (2005) they found that the reduction in a -esterase was obtained in laboratory and field strain of $S$. littoralis treated with six IGR. 


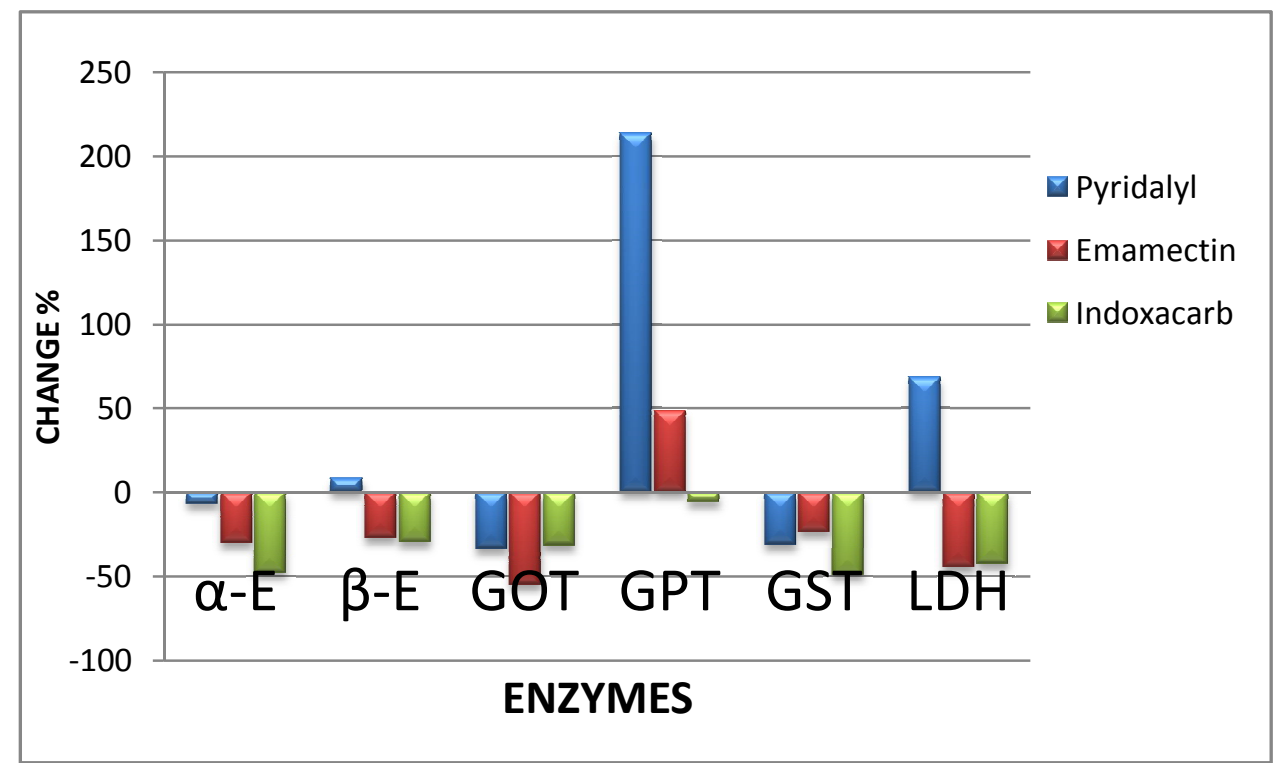

Fig 1 . Changes\% in enzymes activity of $S$. littoralis post 48 hrs of treatment $4^{\text {th }}$ instar larvae with $\mathrm{LC}_{50}$ values of three insecticides.

It is interesting to note that the increasing activity of several detoxification enzymes such as esterases have been shown to protect insect from insecticide poisoning as a part of defense mechanism, or added stress on enzyme expression system to synthesize new and higher amount of detoxification enzymes where could be the possible reasons for the arrested growth and mortality (Wheeler and Isman 2000). Also, a growth regulator such as juvenile hormone could be assumed to be the cause of the long larval periods and the high non specific esterase induction (Howard et al.,1986). (Muthusamy et al., 2011) reported that increasing activity of esterase enzymes post treatment and decreasing with high dose that may be due to the decrease of body weight defense against insecticide stress. Accordingly, acetylcholinesterase enzymes may play an important role in detoxification of synthetic pyrethroid and organophosphates in S. litura.

\section{2- Transaminases enzymes activities:}

\section{a- Glutamic oxaloacetic transaminase (GOT)}

All the tested insecticides gave the same pattern of change in the activity of GOT of the $4^{\text {th }}$ of $S$. littoralis (Table.3 and Fig. 1\&2), they caused a high significant reduction in the enzymetic activity. The maximum reduction $(-54.96 \%)$ was recorded by emamectin benzoate while pyridelyl and indoxacarb caused moderate significant reduction which being -37.77 and $-31.61 \%$, respectively compared with control. Whereas there were no significant differences between pyridalyl and indoxacarb insecticides. 
The activity ratios based on control it proved less by $0.68,0.45$ and 0.62 time for indoxacarb, emamectin benzoate and pyridelyl, respectively.

Table 3. changes in GOT activity of $S$. littoralis post $48 \mathrm{hrs}$ of treatment $4^{\text {th }}$ instar larvae with $\mathrm{LC}_{50}$ values of three insecticides.

\begin{tabular}{|c|c|c|c|c|}
\hline Insecticides & Indoxacarb & Emamectin & Pyridalyl & control \\
\hline$*$ Mean \pm SE & $2946.33 \pm 53.45 \mathrm{~b}$ & $1940.33 \pm 30.2 \mathrm{c}$ & $2681.0 \pm 34.66 \mathrm{~b}$ & $4308.0 \pm 130.99 \mathrm{a}$ \\
\hline Change\% & -31.61 & -54.96 & -33.77 & - \\
\hline Activity ratio & 0.68 & 0.45 & 0.62 & - \\
\hline F value & \multicolumn{3}{|c|}{$185.147 * * *$} \\
\hline L.S.D & 242.55 & - \\
\hline
\end{tabular}

${ }^{*}$ Mean with the same letter are not significant different.

*Mean: Ux103\% g.b.wt.

SE: Stander error.

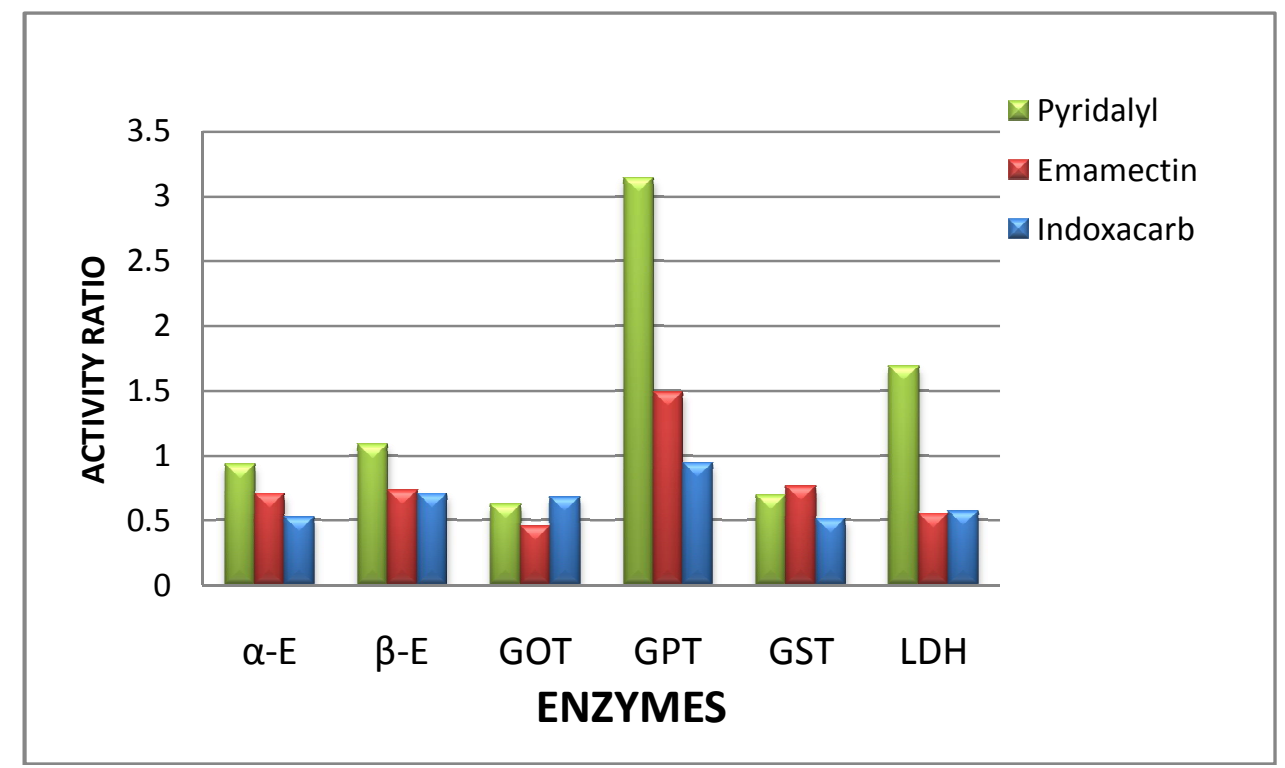

Fig 2. Ratios in enzymes activity 48 hrs of treating $4^{\text {th }}$ after instar larvae with $\mathrm{LC}_{50}$ values of three insecticides.

\section{b- Glutamic pyruvic transaminase (Gpt).}

GPT showed highly significant stimulation in the enzyme activity (Table 4 and Fig. 1\&2). The maximum increase level was $+213.95 \%$ caused by pyridalyl treatment , whereas emamectin benzoate recorded moderate increase to reach $+48.72 \%$. On the other hand, indoxacarb recorded low significant decrease in GPT by $-6.17 \%$.

The activity ratio, GPT was enhanced by 3.14 and 1.49 times as a result of treated by pyridalyl and emamectin benzoate, while indoxacarb was 0.94 time less than control, respectively.

It was appeared from the obtained results that the treatment of $S$. littoralis larvae with $\mathrm{LC}_{50}$ values of three insecticides gave drastic changes in the transaminases 
activity. The changes was more pronounced in GPT than GOT. Regarding GOT and GPT activites. Indoxacarb caused reduction in GOT and GPT by -31.61 and $6.17 \%$, respectively. Pyridalyl and emamectin benzoate caused significant reduction in GOT by -37.77 and $-54.96 \%$, respectively while pyridalyl caused highly significant increase by $+213.95 \%$ in GPT activity followed by significant increase by $+48.72 \%$ for emamectin benzoate.

Table 4. changes in GPT activity of $S$. littoralis post $48 \mathrm{hrs}$ of treatment $4^{\text {th }}$ instar larvae with $\mathrm{LC}_{50}$ values of three insecticides.

\begin{tabular}{|c|c|c|c|c|}
\hline Insecticides & Indoxacarb & Emamectin & Pyridalyl & Control \\
\hline$*$ Mean \pm SE & $973.33 \pm 20.6 \mathrm{c}$ & $1542.67 \pm 33.2 \mathrm{~b}$ & $3257.67 \pm 63.5 \mathrm{a}$ & $1037.33 \pm 23.25 \mathrm{c}$ \\
\hline Change\% & -6.17 & +48.72 & +213.95 & - \\
\hline Activity ratio & 0.94 & 1.49 & 3.14 & - \\
\hline F value & \multicolumn{4}{|c|}{$747.235 * * *$} \\
\hline L.S.D & 127.29 & \\
\hline
\end{tabular}

*Mean with the same letter are not significant different.

*Mean: Ux103\%g.b.wt.

SE: Stander error.

The obtained results are in harmony with that recorded by Abd El Hafez et al.(1993) stated that, treatment of S. littoralis larvae with cyanophos, Methomyl and two IGR and their mixtures caused variable reduction in Got and Gpt enzymes exhibited much increase in its activity comparing with control. Got for the field and laboratory strains of $S$. littoralis treated with six IGR were inhibited by (-3.69 and $28.14 \%$ ), respectively and the same trend recorded in Gpt and the inhibition ranged between (-13.85 and-42.17\%) for laboratory and field strain, respectively (Anwar and Abd El Mageed 2005).

\section{Glutathione- S- transferase (GST):}

In Table (5) and Fig.( 1 ) revealed that GST activity generally was reduced as a results of treated $4^{\text {th }}$ instar larvae with three tested insecticides. The most reduced GST activity was noted with indoxacarb treatment (-48.98\%) followed pyridalyl and emamectin benzoate induced significant reduction ranged between -31.12 and $23.97 \%$, respectively compared with control. There was no significant difference between emamectin and pyridalyl on the enzymatic activity.

As shown in Table (5) and Fig.(2), the relative activity ratios indoxacarb, emamectin and pyridalyl were $0.51,0.76,0.69$ time less than control.

These results agreed with those recorded by Muthusamy et al., (2011) recorded that GST was 2 fold less in $\boldsymbol{\lambda}$-cyhalothrin treatment than dichlorvos. However in both treatments the enzymatic activity was decreased compared with control. In supporting 
this reduction organophosphate and synthetic pyrethroid interfere with GST mediated detoxification to low and high concentrations (Buyukguzel, 2009).

Table 5. changes in GST activity of $S$. littoralis post 48 hrs of treatment $4^{\text {th }}$ instar larvae with $\mathrm{LC}_{50}$ values of three insecticides.

\begin{tabular}{|c|c|c|c|c|}
\hline Insecticides & Indoxacarb & Emamectin & Pyridalyl & Control \\
\hline *Mean \pm SE & $33.33 \pm 2.03 \mathrm{c}$ & $49.67 \pm 0.88 \mathrm{~b}$ & $45.0 \pm 2.08 \mathrm{~b}$ & $65.33 \pm 2.6 \mathrm{~b}$ \\
\hline Change\% & -48.98 & -23.97 & -31.12 & - \\
\hline Activity ratio & 0.51 & 0.76 & 0.69 & - \\
\hline F value & \multicolumn{4}{|c}{$43.91^{* *}$} \\
\hline L.S.D & 6.522 & \\
\hline
\end{tabular}

*Mean: $\mathrm{mmol}$ subs. conjugated/min/g.b.wt.

*Mean with the same letter are not significant different.

SE: Stander error.

\section{Lactic dehydrogenase (LDH):}

A highly significant increase in the activity of LDH (Table 6 and Fig. 1\&2) was recorded by pyridalyl ( $+68.66 \%$ ) which considered the most effective insecticides on LDH activity. On the other hand, no significant differences in the activity were recorded between emamectin benzoate and indoxacarb treatment. Whereas the reduction percentages were -44.87 and $-42.75 \%$, respectively compared with the control.

Activity ratio of pyridalyl was enhanced by 1.69 times, while indoxacarb and emamectin benzoate were inhibited by 0.57 and 0.55 time, respectively less to control.

Table 6. changes in LDH activity of $S$. littoralis post $48 \mathrm{hrs}$ of treatment $4^{\text {th }}$ instar larvae with $\mathrm{LC}_{50}$ values of three insecticides.

\begin{tabular}{|c|c|c|c|c|}
\hline Insecticides & Indoxacarb & Emamectin & Pyridalyl & Control \\
\hline$*$ Mean \pm SE & $721 \pm 12.4 \mathrm{c}$ & $694.33 \pm 9.8 \mathrm{c}$ & $2124.0 \pm 97.43 \mathrm{a}$ & $1259.33 \pm 37.7 \mathrm{~b}$ \\
\hline Change\% & -42.75 & -44.87 & +68.66 & \\
\hline Activity ratio & 0.57 & 0.55 & 1.69 & \\
\hline F value & \multicolumn{3}{|c}{} & \\
\hline L.S.D & \multicolumn{3}{|c}{$142.692 .21 * *$} \\
\hline
\end{tabular}

*Mean: Ux103\%g.b.wt.

*Mean with the same letter are not significant different.

SE: Stander error. 
The obtained results are agree with that recorded by Fahmy and Dahi, (2009) where spinotram had inhibitory effect on LDH with a range between -46.59 and $55.75 \%$ for kalyobia and behiara strains of $S$. litttoralis and the suppression of LDH level due to treatment demonstrating low nutritional efficiency of larvae since LDH is important glycolytic enzymes and can used as indicator of exposure to insecticide (Diamantino et al.,2001).

The same results were recorded by Nathan et al., (2005) on S. littura LDH activity they stated that highly reduction in the enzymatic activity caused by the treatment with azadirachtin or rice striped stem borer treated with diazinon (Zibaee et al.,2008).

Pyridalyl caused a highly significant increase in LDH activity (+68.66\%), add stress on the enzyme expression system to synthesize a new and higher amounts of detoxification enzymes could be possible reasons for the arrested growth and mortality. Lactate dehydrogenase is an enzyme that catalyzes the inter conversion of lactic and pyruvic acid and it is a hydrogen transfer enzyme. Very high activities are found in the heart, skeletal muscle and present in lesser amounts in the smooth muscle and brain (Michael, 1980; Wheeler and Isman; 2000). LDH activity plays a key role by catalyzing, during contraction, the formation of relaxation the reverse process occurs and pyruvate is metabolized via the tricarboxylic acid cycle.

There is evidence that glycolysis is the major source of energy for muscle contraction in most insect (kitto and Birggs, 1962). LDH is not a component of the enzyme systems involved in fat metabolism. LDH activity is probably control by temporal action of regulatory genes.

In general, the three tested insecticides had different degree of effect on the activity of the six enzymes. All the insecticides had inhibition effect on all enzymes except GPT, LDH and $\beta$ - esterase showed highly significant increase post pyridalyl treatment. Also, emamectin benzoate caused a significant increase only on GPT.

So the death of insect results from combination factors such as mechanical damage which resulting from tissue invasion, depletion of nutrient resources, enzymatic disturbance and toxicosis. 


\section{REFERENCES}

1. Abd El -Hafez, M. M., A. Mohanna, M. A. Afifi, and A. H. Eid. 1993. Effect of IGR insecticide mixtures on esterase activity of Spodoptera littoralis . J. product. and Dev., 1:153-164.

2. Anwar, E. M. and A.E.M. Abd El-Mageed. 2005. Toxicity impacts of certain insect growth regulators on some biochemical activities of the cotton leafworm. Egypt. J. Agric. Res., 83(3) 915-935

3. Bakr, F. A. Reda, M. El-barky, Nehad, Abd El aziz, F. Mona, Awad, H. Mohamed and M. E. Hisham, AbdEI-Halim. 2010. Effect of chitin synthesis inhibitions (Flufenoxuron) on some biological and biochemical aspects of cotton leaf worm Spodoptera littoralis (Boisd.). Egypt. Acad. J. Biol. Sci., 2 (2):43-56.

4. Buyukguzel, Ender. 2009. Evidence of oxidative and antioxidative responses by Galleria mellonella larvae to malathion. J. Econ. Entomol. 102: 152-159.

5. Deutsche Gesellschaft FÜr Klinische Chemie. 1972. Empfehlungender Deutschen Gesellschaft FÜr Klinische Chemie. J. clin. chem. Biochem., 10 : 182-193.

6. Dinter, A. and A. J. Wiles. 2000. Safety of the new Du pont insecticide indoxacarb to beneficial arthropoda an overview. IOBC/Wp RS Bulletin 23: 149156.

7. El-Defrawi, M. E., A. Toppozada, N. Mansour and M. Zaid. 1964. Toxicological studies on Egyptian cotton leafworm Prodenia litura L. (F.). Susceptibility of different larval instars to insecticides. J. Econ. Entomol., 57(4):591-593.

8. Fahmy, M. Nedal and F. Hassan, Dahi. 2009. Changes in detoxifying enzymes and carbohydrate metabolism associated with spinetoram in two field-collected strains of Spodoptera littoralis (Bosid.). Egypt, Acad. J. Biol. Sci., 1 (1): 15-26.

9. Fritz, L. C. , C. C. Wang and A. Gorio. 1979. Avermectin B. irreversibly blocks post synaptic potential at the lobster neuromuscular function reduction muscle membrane resistance. Proc. Natl. Acad. Sci. U. S.A.76:2062-2066.

10. Habig, W. H., M. J. Pabst and W. B. Jakoby. 1974. Glutathion- S- Transferases. The first enzymatic step in mercaptturic acid formation. J. Biol. Chem. 149: 7130-7139.

11. Howard, W. F., R. L. Rose, T. C. Sparks and A. M. Hammond. 1986. Juvenile hormone esterase activity in developmentally synchronous ultimate stadium larvae of the migrant insect, Anticarsia gemmatalis. J. Insect Physiol. 33 (12): 1055-1063.

12. Kitto, G. B. and M. H. Birggo. 1962. Lactate hydrogenase in some muscles. Nature, 193: 1003-1004. 
13. Lasota, R. K. and R. A. Dybas. 1991. Avermactins, a novel class of compounds: implication for use in arthropod pest control. Annu. Rev. Entomol. 36:91-117.

14. Leona, I. N. and N. M. Slynko. 1998. Comparative study of insecticide susceptibility and activities of detoxification enzymes in larvae and adults of cotton bollworm. Archives insect Biochem. and physiol. 32:157-172.

15. Michael, F. 1980. Enzymes in "Clinical Chemistry" $3^{\text {rd }}$ Edition, pp. 218-219.

16. Muthusamy, Shivakumar, Karthi, Ramkumar and salem, Tamilnadu. 2011. Pesticide detoxifying mechanism in field population of Spodoptera litura (Lepidoptera: noctuidae) from south India. Egypt. Acad. J. Biolog. Sci., 3 (1): 5157.

17. Nathan, S. S., K. Kalaivani and P. G. Chung. 2005. The effects of azadirachtin and nucleopolyhydrovirus on midgut enzymatic profile of Spodoptera litura Fab. (Lepidoptera: Noctuidae). Pestic. Biochem. Physiol. 83: 46-57.

18. Reitman, S. M. and S. Frankle. 1957. A colorimetric method for the determination of serum glutamic-oxaloacetic and glutamic- pyruvic transaminase. Ann. J. Clin. Pathol., 28:56-62.

19. Van asperen, K. 1962. A study of house fly esterase by means of sensitive colorimetric method. J. Insect Physiol., 8: 410-416.

20. Wheeler, D. A. and M. B. Isman. 2000. Effect of Trichilia Americana extract on feeding behavior of Asian armyworm, Spodoptera litura.J. Chem. Ecol. 26:27912800.

21. Zibaee, A., J. J. Sendi, K. Etebari, F. Alinia and M. Ghadamyari. 2008. The effect of diazinon on some biochemical characteristics of chilo suppressalis walker (Lepidoptera: Pyrialidae), rice striped stem borer. Mum. Entomol., Zool., 3(1): 255-265. 


\title{
تاثير بعض المبيدات الحشرية على مستوى \\ النشاط الا نزيمى لاودة ورق القطن
}

\author{
حنان صديق عبد العزيز \\ معرد بحوث وقاية النبات - مركز البحوث الزراعية - دقى - جيزه
}

الهدف من الدراسة القاء الضوء على الدور الحيوى الذى تقوم به المبيدات المنتمية الى

مجموعات مختلفة وهي البيريداليل، اندوكسيكارب، ايماميكثين بنزوات ومدى سميتها على دودة ورق لنور

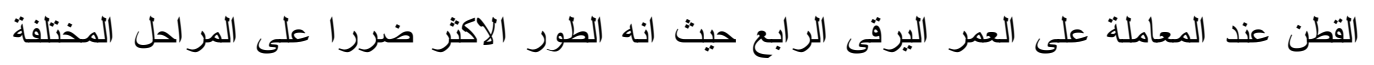

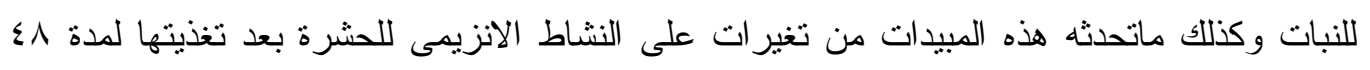

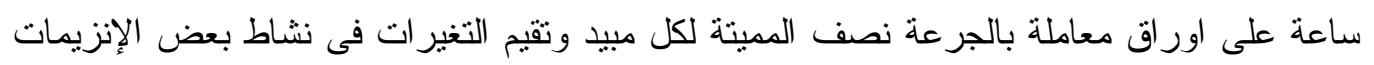
وهي و وايضا (Gpt), glutamic oxaloacetic transaminase (Got), glutathione-S- transferase (Gst) lactate dehydrogenase (LDH) تثتيط بعض الانزيمات وزيادة في البعض الاخر حيث كان اندوكسيكارب اكثر تتبيطا لنشاط

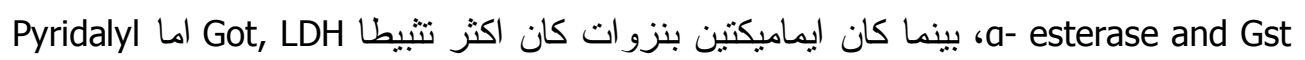

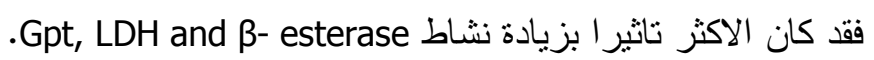

